\title{
Editorial: Positive News About the Future of Philosophy of Education
}

\author{
Gert Biesta
}

Published online: 6 December 2014

(C) Springer Science+Business Media Dordrecht 2014

In 1999 I was approached by Jim Garrison (then editor-in-chief of Studies in Philosophy and Education) and Terry McLaughlin (then chair of the International Network of Philosophers of Education) with the question whether I was willing to become the next editor of Studies in Philosophy of Education. I was honoured by the request and started working behind the scenes from the end of that year onwards. Fifteen years later I come to the end of my editorship and it gives me great pleasure to introduce and welcome Barbara ThayerBacon as the next editor-in-chief of Studies in Philosophy and Education. Barbara brings a wealth of experience to the task and a deep insight in the international field of philosophy of education. What also gives me great pleasure is that at last one of the major international English-language philosophies of education journals will have a female editor. I am extremely pleased that Studies in Philosophy and Education is making history-although it has been long overdue. In this editorial I would like to identify a number of memorable events that occurred during my editorship, and want to provide some reflections about the future of philosophy of education.

When I took over as editor, Studies in Philosophy and Education was a rather small journal with probably somewhere in the range of 400 paper subscriptions world-wide. Although it performed a role within the field of philosophy of education, it is obvious that even with library subscriptions included, its reach must have been rather modest. Perhaps the most significant change during my editorship, then, has been the move towards electronic publishing and the subsequent decision of the publisher to offer the journal as part of a bundle of journals to libraries, rather than in the form of single subscriptions. This has not only significantly increased the number of subscriptions to the journal, but has also dramatically increased the readership of the journal, with annual download figures in the 50,000 region in recent years. This can only mean that there is a large group of people 'out there' with a real interest in the kind of work published in Studies in Philosophy and

G. Biesta $(\bowtie)$

Department of Education, Brunel University London, London, UK

e-mail: gertbiesta@gmail.com 
Education, and from my interaction with fellow-editors in the field I know that their journals have experienced similar trends which, by and large, I consider to be very good news for our field.

Another significant event during my tenure as editor has been the inclusion of the journal in the Social Science Citation Index. While I continue to have doubts about such systems, also because in some national contexts and settings they are being used for playing very particular political 'games' of exclusion, I did find it important to show that the scholarship represented in Studies in Philosophy of Education really belongs in such indexes alongside other forms of scholarship in the educational and social sciences, and that it should not be seen as inferior to, say, empirical research. From this angle I consider the inclusion of the journal in the SSCI another bit of good news for the field. The journal also celebrated its 50th anniversary during my editorship-with 30 volumes published during that period-something we celebrated with a special issue, which was subsequently published as a book (see Biesta 2011, 2012).

Over the 15 years I have not only seen a significant increase in the number of readers, but there has also been a steady increase in manuscript submissions, which was one of the reasons why, already early on during my editorship, the journal moved from 4 to 6 issues annually-an increase in the annual page budget of $50 \%$. What has also been pleasing from my perspective is that over the years - but probably only noticeable in recent yearsthe geographical location of the authors being published in the journal has widened. I am aware that there is an inherent contradiction in the idea of an English-language international journal - a contradiction with which, for the moment, we may need to have to livebut at least a broader range of authors is becoming visible through the journal.

Although being an editor can sometimes be a rather lonely task, I have always felt supported by an impressive editorial board. Over the years I have not only been able to make the board more international. I have also tried, from time to time, to bring about what might be called a 'generational update,' so as to secure that the composition of the board kept pace with the development of the field. I have also had the good fortune to work with three fantastic book-review editors-Evelina Orteza y Miranda, Ann Chinnery and Sam Rocha-who all have made significant contributions to the book-review section of the journal, a section I value very much because it now only allows for extended review essays, but always also gives authors the opportunity for a response. In a time where book reviewing has a rather low status in promotion and tenure reviews, I have been impressed by the high quality of reviews and reviewers that the journal has been able to publish, and I know that a lot of this is due to the personal efforts of the book review-editors. I would also like to mention the support I have received from the publishers. Over the years, I have worked with a number of great editors who have all been keen to provide full support for the journal and have contributed significantly to the journal's ongoing success. And finally I wish to express my gratitude to the authors-both those who have had their work accepted and those who had their work rejected-and acknowledge the generosity of numerous reviewers without whom it would have been impossible to maintain the high standard of quality I hope the journal has managed to achieve. I have very much enjoyed the interaction with authors and reviewers, have been pleased when I was able to provide them with good news and have also been pleased by the way in which authors for whom my news was not positive have responded. Sending rejection letters has remained the hardest part of my task as editor.

What then about the future of philosophy of education? Given the developments I have witnessed over the past 15 years I am generally quite positive-and I also feel that it is important to remain positive even if in some cases the circumstances under which we work 
are telling us the opposite. I am of course very aware that, at an institutional, level positions in philosophy of education and in the foundations of education more generally have declined and are continuing to decline in many countries around the world. There have been significant shifts towards more empirical and more utilitarian forms of educational research and scholarship which, in many cases, have led to an institutional marginalisation of work in the theory and philosophy of education-something I have also witnessed in my own career (see Biesta 2014).

But whereas the institutional position of philosophy of education has significantly declined, the volume and quality of scholarship in the theory and philosophy of education has dramatically increased, and this trend appears to be ongoing. This not only means that many remain convinced about the value of this kind of work for educational research and educational practice. It also means that many who are currently doing philosophical work in education have been able to find other places within higher education from which they do this work. There is something good about this, because it may mean that philosophy of education has become more integrated in the wider field of educational research and scholarship. But we have to bear in mind, of course, that this also comes at a price, particularly that of institutional status and visibility. Positions that are not labelled as 'philosophy of education' can easily be redesignated if the person occupying the position leaves. That is why it remains important to argue for the institutional status of the theory and philosophy of education. The health of the scholarship in the field, as evidenced in the way in which Studies in Philosophy and Education has developed over the past 15 years, can at least provide one strong argument for the ongoing efforts to show the value and importance of this kind of work for the wider field of educational research and, ultimately, for the everyday practice of education. I hope that Studies in Philosophy of Education will continue to make a significant contribution to this task.

\section{References}

Biesta, G. J. J. (2011). An adventure in publishing revisited. Fifty years of studies in philosophy and education. Studies in Philosophy and Education, 30(5), 429-432.

Biesta, G. J. J. (Ed.). (2012). Making sense of education: Fifteen contemporary educational theorists in their own words. Dordrecht/Heidelberg/New York: Springer.

Biesta, G. J. J. (2014). From experimentalism to existentialism: Writing from the margins of philosophy of education. In L. Waks (Ed.), Leaders in philosophy of education (Vol. II, pp. 13-30). Rotterdam/ Boston/Taipei: Sense. 